|| ISSN(online): 2589-8698 || ISSN(print): 2589-868X || International Journal of Medical and Biomedical Studies

Available Online at www.ijmbs.info

Volume 3, Issue 2; February: 2019; Page No. 26-29

PubMed (National Library of Medicine ID: 101738825)

Index Copernicus Value 2017: 40.03

\title{
A STUDY OF INCIDENCE OF ANTE-PARTUM HEMORRHAGE AND ITS TYPES AT TERTIARY HEALTH CARE CENTRE
}

\author{
Dr. Pratibha. Patil ${ }^{1}$, Dr. Sanjay Patil ${ }^{2^{*}}$ \\ ${ }^{1}$ Associate Professor, Dept. of Obstetrics and Gynecology, RIMS, Raipur, Chattisgarh, India. \\ ${ }^{2 *}$ Professor, HOD, Dept. of Obstetrics and Gynecology, RIMS, Raipur, Chattisgarh, India.
}

Article Info: Received 17 January 2019; Accepted 13 February. 2019

Cite this article as: Patil, Dr.P., \& Patil, Dr.S. (2019). A STUDY OF INCIDENCE OF ANTE-PARTUM HEMORRHAGE

AND ITS TYPES AT TERTIARY HEALTH CARE CENTRE. International Journal of Medical and Biomedical

Studies, 3(2).

DOI: https://doi.org/10.32553/ijmbs.v3i2.89

Address for Correspondence: Dr. Sanjay Patil, Professor, HOD, Dept. of Obstetrics and Gynecology, RIMS,

Raipur, Chattisgarh, India.

Conflict of interest: No conflict of interest.

\begin{abstract}
Introduction: Worldwide approximately 830 women die every day from preventable causes related to pregnancy and childbirth; $99 \%$ of those 830 daily deaths are women from developing countries.

Aims and Objectives: To Study incidence of ante-partum hemorrhage and its types at tertiary health care centre

Methodology: This study was conducted in Medical College \& General hospital, in the Department of Obsterics \& Gynecology. A Total no. of 104 cases of antepartum hemorrhage admitted in hospital were studied \& analyzed .In the present study all patients who had bleeding from genital tract after 20 weeks of gestation \& before second stage of labor were included. The data was entered in excel sheets and analyzed and presented in tabular form expressed in percentages.

Result: In our study we have seen that the majority of the patients were of Placenta previa were $1.39 \%$, followed by Abruption placenta Were $-0.93 \%$, Local lesions were $0.05 \%$, Unclassified group were $0.05 \%$, Total APH were $-2.42 \%$, Of the Total No. of deliveries 4307 . The majority of the patients were in the age group of $21-25$ were $-37.50 \%, 26-30-28.84 \%, 16-20-20.20 \%, 31-35-9.62 \%, 35 \&$ above were $2.84 \%$. The majority of the patients of APH were of Third party were $-25.00 \%$, Second $-21.15 \%$, Primi$18.27 \%$, Fourth $-16.34 \%$, Fifth and Sixth \& above were $-9.62 \%$. Placenta previa was more common in Third- 26.67\%, followed by Second - 23.33\%, and Primi $-16.27 \%$. Abruptio placenta placenta was more common in Primi and Third-22.5\%, second and fifth was $17.5 \%$, sixth \& above were $12.5 \%$. This observed difference was not statistically significant $(p>0.05)$.

Conclusion: In our study we have seen that the majority of the patients were of Placenta previa, the majority of the patients were in the age group of 21-25, the majority of the patients of APH were of Third party. Placenta previa was more common in Third parity Abruptio placenta placenta was more common in Primi and followed by Second Third parity.
\end{abstract}

Key words: Ante-Partum hemorrhage (APH), Abruptio placenta, Placenta previa, Anemia of chronic disease, Microcytic hypochromic anemia. 


\section{Introduction:}

Worldwide approximately 830 women die every day from preventable causes related to pregnancy and childbirth; $99 \%$ of those 830 daily deaths are women from developing countries. [1] Direct obstetrical complications are the main causes of maternal deaths, with bleeding [2] identified as the first cause. In Burkina Faso maternal mortality remains high, with 2,700 deaths per 100,000 deliveries [1] . Hemorrhage is the leading cause of maternal mortality globally, accounting for approximately $27 \%$ of deaths worldwide; this includes postpartum, intrapartum and antepartum hemorrhage []ㅡ. In developed countries, hemorrhage prior to delivery accounts for only $16.3 \%$ of maternal deaths, while Sub-Saharan Africa remains high at 24.5\%. Antepartum Hemorrhage (APH) is defined as bleeding from the vagina after 24 weeks [4] France [ㄷ] Serious Obstetrical Hemorrhage $(\mathrm{SOH})$ represented $19 \%$ of admissions to the Intensive Care Unit (ICU). Worldwide postpartum hemorrhage (PPH) has been well studied, but $\mathrm{APH}$ and intrapartum hemorrhage (IPH) are less well-documented. APH is an obstetric emergency significantly contributing to perinatal and maternal morbidity and mortality. PPH yields mainly maternal complications and may be in itself a complication of APH. However, during APH, complications can be fetal as well as maternal. The maternal complications are malpresentation, premature labor, $\mathrm{PPH}$, sepsis, shock and retained placenta []ㅡ. Various fetal complications are prematurity, low birth weight, intrauterine death, congenital malformation and birth asphyxia []].

\section{Material and methods:}

This study was conducted in Medical College \& General hospital in the Department of Obsterics \& Gynecology from. A Total no. of 104 cases of antepartum hemorrhage admitted in hospital were studied \& analyzed .In the present study all patients who had bleeding from genital tract after 20 weeks of gestation \& before second stage of labor were included. The data was entered in excel sheets and analyzed and presented in tabular form expressed in percentages.

\section{Result}

Table 1: Distribution of the patients as per the type and incidence of APH

\begin{tabular}{|c|c|c|}
\hline & No. & Percentage (\%) \\
\hline Placenta previa & 60 & 1.39 \\
\hline Abruption placenta & 40 & 0.93 \\
\hline Local lesions & 2 & 0.05 \\
\hline Unclassified group & 2 & 0.05 \\
\hline Total APH & 104 & 2.42 \\
\hline Total No. of deliveries & 4307 & 100.00 \\
\hline
\end{tabular}

The majority of the patients were of Placenta previa were 1.39\%, followed by Abruption placenta Were $-0.93 \%$, Local lesions were $0.05 \%$, unclassified group were $0.05 \%$, Total APH were $2.42 \%$ Of the Total No. of deliveries 4307.

Table 2: Distribution of the patients as per the age

\begin{tabular}{|l|l|l|}
\hline Age (years ) & No. of cases $(\mathrm{n}=104)$ & Incidence $(\%)$ \\
\hline $16-20$ & 21 & 20.20 \\
\hline $21-25$ & 39 & 37.50 \\
\hline $26-30$ & 30 & 28.84 \\
\hline $31-35$ & 10 & 9.62 \\
\hline $35 \&$ above & 4 & 2.84 \\
\hline Total & 104 & 100.00 \\
\hline
\end{tabular}


The majority of the patients were in the age group of $21-25$ were $-37.50 \%, 26-30-28.84 \%, 16-20-20.20 \%, 31-$ 35- $9.62 \%, 35$ \& above were $2.84 \%$.

Table 3: Distribution of the patients as per the parity

\begin{tabular}{|c|c|c|}
\hline Parity & No. of cases $(\mathrm{n}=104)$ & Incidence (\%) \\
\hline Primi & 19 & 18.27 \\
\hline Second & 22 & 21.15 \\
\hline Third & 26 & 25.00 \\
\hline Fourth & 17 & 16.34 \\
\hline Fifth & 10 & 9.62 \\
\hline Sixth \& above & 10 & 9.62 \\
\hline Total & 104 & 100.00 \\
\hline
\end{tabular}

Table 4: Distribution of the patients as per the parity and type of APH

\begin{tabular}{|l|l|l|l|l|}
\hline Parity & $\begin{array}{l}\text { Placenta previa } \\
(\mathrm{n}=60)\end{array}$ & $\begin{array}{l}\text { Abruptio } \\
\text { placenta }(\mathrm{n}=40)\end{array}$ & $\begin{array}{l}\text { Local causes } \\
(\mathrm{n}=2)\end{array}$ & $\begin{array}{l}\text { Unclassified } \\
(\mathrm{n}=2)\end{array}$ \\
\hline Primi & $10(16.27 \%)$ & $9(22.5 \%)$ & - & - \\
\hline Second & $14(23.33 \%)$ & $7(17.5 \%)$ & $1(50.0)$ & - \\
\hline Third & $16(26.67 \%)$ & $9(22.5 \%)$ & - & $1(50.0)$ \\
\hline Fourth & $13(21.66 \%)$ & $3(7.5 \%)$ & $1(50.0)$ & - \\
\hline Fifth & $3(5.00 \%)$ & $7(17.5 \%)$ & - & - \\
\hline Sixth \& above & $4(6.67 \%)$ & $5(12.5)$ & - & $1(50.0)$ \\
\hline
\end{tabular}

Placenta previa was more common in Third$26.67 \%$, followed by Second $-23.33 \%$, and Primi 16.27\%. Abruptio placenta placenta was more common in Primi and Third-22.5\%, Second and fifth were $17.5 \%$ Sixth \& above were $12.5 \%$. This observed difference was statistically significant ( $p>0.05$ ).

\section{Discussion:}

The leading cause of maternal mortality in world is obstetric haemorrhage. ${ }^{8}$ Antepartum haemorrhage (APH) is defined as bleeding from or into the genital tract after 28 weeks of pregnancy and before delivery of the baby. ${ }^{9}$ The prevalence of this obstetric emergency varies from hospital to hospital i.e. $0.5-5 \% .{ }^{10}$ The main causes of APH are placenta previa, abruption placentae, indeterminate cause or local causes of genital tract. In developed countries, maternal mortality due to antepartum haemorrhage has been reduced significantly due to better obstetrical facility and care. But in developing countries like India maternal and perinatal mortality is still very high due to associated problems like anaemia, difficulties in transport in cases of emergency and restricted medical facilities. ${ }^{11}$ The complications in pregnancies complicated with APH are malpresentation, premature labour, postpartum haemorrhage, shock, retained placenta, higher rates of caesarean sections, peripartum hysterectomies, coagulation failure and maternal, death. Perinatal complications include premature delivery, low birth weight, intrauterine death, congenital malformations and birth asphyxia. ${ }^{12,13}$ Because of increase in the caesarean section rates, there is an increase in the incidence of placenta praevia and morbidly adherent placenta. In developing countries like India, among the causes of abruption placentae, hypertensive disorders of pregnancy like gestational hypertension and preeclampsia and folic acid deficiency are considered as important etiological factors. ${ }^{13,14} \mathrm{APH}$ is one of the important cause postpartum haemorrhage. In our study we have seen that The majority of the patients were of Placenta previa were 1.39\%, followed by Abruption placenta Were $-0.93 \%$, Local lesions were $0.05 \%$, Unclassified group 
were $0.05 \%$, Total APH were $-2.42 \%$, Of the Total No. of deliveries 4307.

The majority of the patients were in the age group of $21-25$ were $-37.50 \%, 26-30-28.84 \%$, 16-20- 20.20\%, 31-35- 9.62\%, 35 \& above were $2.84 \%$. The majority of the patients of APH were of Third party were $-25.00 \%$, Second $-21.15 \%$, Primi-18.27\%, Fourth $-16.34 \%$, Fifth and Sixth \& above were $-9.62 \%$. Placenta previa was more common in Third- $26.67 \%$, followed by Second 23.33\%, and Primi $-16.27 \%$. Abruptio placenta placenta was more common in Primi and third$22.5 \%$, second and fifth were $17.5 \%$, Sixth \& above were $12.5 \%$. This observed difference was not statistically significant $(p>0.05)$.

\section{Conclusion:}

In our study we have seen that the majority of the patients were of Placenta previa, The majority of the patients were in the age group of 21-25, The majority of the patients of APH were of Third party. Placenta previa was more common in Third parity; Abruptio placenta placenta was more common in Primi and followed by Second Third parity.

\section{References:}

1. WHO, UNICEF, UNFPA, World Bank Group and the United Nations Population Division. Trends in maternal mortality: 1990 to 2015. Fact sheet $\mathrm{N}^{\circ} 348, \mathrm{WHO} / \mathrm{RHR} / 15.23: 2015 ; 12$. http://apps.who.int/iris/bitstream/10665/19 4254/1/9789241565141_eng.pdf?ua=1

2. Magnin G. Hémorragies du troisième trimestre de la grossesse. Rev Pratic. 1997;47:1470-1.

3. Say $L$, Chou $D$, Gemmill $A$, Tunçalp Ö, Moller $A B$, Jane $D$, Gülmezoglu $A M$, Temmerman $M$, Alkema L. Global causes of maternal death: a WHO systematic analysis. Lancet Glob Health. 2014;2:e323-33. doi: 10.1016/S2214 -109X(14)70227-X.

4. Wasnik SK, Naiknaware SV. Antepartum hemorrhage: causes \& its effects on mother and child: an evaluation. Obstet Gynecol Int J. 2015;3(1):00072.
5. Koeberlé $P$, Lévy $A$, Surcin $S$, Bartholin $F$, Clément G, Bachour K, Boillot A, Capellier G, Riethmuller D. Complications obstétricales graves nécessitant une hospitalisation en réanimation : étude rétrospective sur 10 ans au CHU de Besançon. Ann Fr Anesth Reanim. 2000;19:445-51. doi: 10.1016/S0750-7658 (00)90218-1.

6. Kedar K, Uikey P, Pawar A, Choudhary A. Maternal and fetal outcome in antepartum haemorrhage: a study at tertiary care hospital. Int J Reprod Contracept Obstet Gynecol. 2016;5:1386-93. doi: 10.18203/ 2320-1770.ijrcog20161291.

7. Cunningham F, Leveno K, Bloom S, Hauth J, Gilstrap L, Rouse D, et al. Obstetrical haemorrhage. Williams obstetrics. 23. New York: McGraw Hill Professionals; 2009. pp. 2-3.

8. Lolonde A, Davis BA, Acosta A. Postpartum haemorrhage today: ICM/FIGO initiative 2004-2006 UGO. 2006;94:243-53.

9. Dutta DC. Antepartum haemorrhage. In Konar. HL ed. Textbook of obstetrics. 6 th ed. Kolkatta:New central book agency;2006:2436.

10. Sheikh F, Khokhar S, Sirichand P, Shaikh R. A study of antepartum haemorrhage: Maternal and perinatal outcome. Medical Channel. 2010;16(2):268-71.

11. Singhal S, Nymphaea, Nanda S. Maternal and perinatal outcome in antepartum haemorrhage: A study at a tertiary care referral institute. The Internet J Gynaecol Obstet. 2008;9(2):5580.

12. Cunningham FG, Leveno KJ, Bloom SL, Hauth JC et al. Williams Obstetrics. Obstetrical haemorrhage. 22nd Edition. McGraw Hill Companies, Inc: 2005:810-20.

13. Ayushma J, Anjali K. Study of obstetric outcome in antepartum haemorrhage. Pana J Med Sci. 2015;5(3):153-7.

14. Sinha $P$, Kuruba N. Antepartum haemorrhage: an update. J Obstet Gynaecol. 2008;28(4):377- 81 